\title{
Changes in translatable mRNA species associated with nutrient deprivation and protease synthesis in Metarhizium anisopliae
}

\author{
Raymond J. St Leger,* Richard C. Staples and Donald W. Roberts \\ Boyce Thompson Institute for Plant Research, Tower Road, Cornell University, Ithaca, NY 14853, USA
}

(Received 14 August 1990; revised 16 December 1990; accepted 31 December 1990)

\begin{abstract}
We have studied the regulation of the extracellular chymoelastase protease (Pr1) of the fungal entomopathogen Metarhizium anisopliae. This enzyme is involved in the penetration of insect cuticle by Metarhizium and other entomopathogenic fungi. Changes in mRNA sequences during starvation-induced synthesis of chymoelastase were investigated by comparing poly $\left(\mathrm{A}^{+}\right) \mathrm{RNAs}$ and their complementary DNA in rapidly growing or nutrient-deprived cultures of Metarhizium. Hybrid-selected translation revealed that three novel polypeptides (41, 40.2 and $29.8 \mathrm{kDa})$ were produced rapidly $(<1 \mathrm{~h})$ during nutrient deprivation; the most intensely translated species (41 kDa) was identified as the primary translation product of Pr1 by examination with anti-Pr1-IgG. Measurement of starvation-specific RNA levels by dot-blot hybridization with $\left[{ }^{32} \mathrm{P} \mid \mathrm{cDNA}\right.$ showed that transcripts were not present in spores but were produced when the formation against a hard surface of infection structures was induced by depletion of endogenous nutrient reserves. Starvation-specific mRNA species failed to appear when new RNA synthesis was blocked with actinomycin $D$, indicating that control is at the level of transcription. Immunoblot analysis with anti-Pr1-IgG showed that Prl protein increased in concert with the appearance of Pr1 transcripts and active enzyme. Two very short lived precursors of Pr1, the primary translation product (41 kDa) and an intermediate $(40.8 \mathrm{kDa})$ in addition to mature $\operatorname{Pr} 1(30 \mathrm{kDa})$ were detected by immunoprecipitation of ${ }^{35}$ S]methionine-labelled cell extracts with anti-Pr1-IgG. Pulse-labelling experiments demonstrated that a time of about 7 min was required for $\left[{ }^{35} \mathrm{~S} \mid\right.$ methionine to be processed into extracellular Pr1. These results suggest that regulation of $\operatorname{Pr} 1$ gene expression occurs during starvation which, coupled with fast processing, allows very rapid secretion of Pr1. Isolates of four other entomopathogenic fungi (Verticillium lecanii, Beauveria bassiana, Tolypocladium niveum and Paecilomyces farinosus) produced Pr1-type enzymes during nutrient deprivation, suggesting our results may have widespread application in understanding entomopathogenicity.
\end{abstract}

\section{Introduction}

The fungal entomopathogen Metarhizium anisopliae penetrates the proteinaceous cuticular barrier of insects by using an extracellular chymoelastase protease $(\operatorname{Pr} 1)$ that constitutes the major protein product synthesized by its infection structures (Goettel et al., 1989; St Leger et al., 1987a, 1989a). The purified enzyme has been characterized for substrate specificity and inhibition by typical serine protease inhibitors (St Leger et al., 1987b). The molecular mass of $\operatorname{Pr} 1$ has been estimated to be 25$31 \mathrm{kDa}$ by various physical means; anomolous estimates may arise from the very basic nature of this protein ( $\mathrm{pI}$ about 10.5, St Leger et al., 1987b). Analogous peptidases

\footnotetext{
Abbreviations: NAG, N-acetylglucosamine; SDA(B), Sabouraud dextrose agar (broth); TLCK, tosyl-lysine chloromethyl ketone; YEM, yeast extract medium.
}

have been resolved in culture filtrates from several other entomopathogenic fungi (St Leger et al., 1987c).

Potentially, specialization for a pathogenic lifestyle may operate by way of regulatory controls which allow expression of genes under conditions in which similar genes are not expressed in non-pathogens. Previously, we demonstrated that antisera against Metarhizium $\operatorname{Pr} 1$ or specific inhibitors of $\operatorname{Prl}$ block penetration of host cuticles and reduce infection indicating that the level of active $\operatorname{Prl}$ may determine the capacity of the fungus to cause disease (St Leger et al., 1988a). Production of the enzyme without differentiation of infection structures can occur rapidly by nutrient deprivation alone (St Leger et al., 1988b) making Metarhizium an amenable system for the study of the molecular controls of protein synthesis. In this study we examined changes in the patterns of Prl synthesis during nutrient deprivation by immunoprecipitation of $\mathrm{Prl}$ from ${ }^{35} \mathrm{~S}$-labelled proteins. 
We also examined the complement of mRNA sequences present during differentiation in two ways. First, we analysed the cell-free translation products of poly $\left(\mathrm{A}^{+}\right)$RNA at different times during nutrient deprivation. Second, we performed subtraction hybridization experiments between poly $\left(\mathrm{A}^{+}\right) \mathrm{RNAs}$ isolated at different times, and their complementary DNA in order to analyse gross changes in the mRNA population during starvation. We discuss our results in terms of different regulatory strategies, as we were particularly interested in whether Prl, being under a comparatively looser form of control by catabolite repression alone, could be regulated as rapidly as those more tightly regulated enzymes induced specifically by the presence of their substrates.

\section{Methods}

Organisms and growth. The fungal isolate (Metarhizium anisopliae ME1) and culture media were described by St Leger et al. (1986a). Isolates of Verticillium lecanii (ARSEF 313), Paecilomyces farinosus (ARSEF 1508), Tolypocladium niveum (ARSEF 616) and Beauveria bassiana (ARSEF 252) were obtained from the USDA-ARS culture collection, Cornell University, Ithaca, NY, USA. The isolates were grown and maintained on Sabouraud dextrose agar (SDA) at $23^{\circ} \mathrm{C}(\mathrm{V}$. lecanii), $25^{\circ} \mathrm{C}\left(B\right.$. bassiana) or $27.5^{\circ} \mathrm{C}$ (other isolates) and stored at $4{ }^{\circ} \mathrm{C}$.

${ }^{35} \mathrm{~S}$ incorporation into proteins. Mycelia from $3 \mathrm{~d} \mathrm{~N}$-acetylglucosamine (NAG) cultures (see below) were collected on Whatman no. 1 filter paper and washed extensively with distilled water. Mycelia ( $1 \mathrm{~g}$ wet $\mathrm{wt}$ ) were then resuspended in $10 \mathrm{ml}$ of chitin medium $(0.5 \%$ chitin, $0.1 \%$ $\mathrm{KH}_{2} \mathrm{PO}_{+}, 0.05 \% \mathrm{MgSO}_{+}, \mathrm{pH} 5.8$ ) and shaken at 75 r.p.m. at $27.5^{\circ} \mathrm{C}$. After $15 \mathrm{~min}$ cultures were monitored at $10 \mathrm{~min}$ intervals for $\mathrm{Prl}$ release. For pulse-labelling experiments, $\left.0.5 \mathrm{mCi}(18.5 \mathrm{MBq}){ }^{35} \mathrm{~S}\right]-$ methionine (Trans ${ }^{35} \mathrm{~S}$, a ${ }^{35} \mathrm{~S}$-labelled bacterial hydrosylate from ICN radiochemicals) was added to cultures and, unless otherwise specified, the mycelia were further incubated for 5-20 min. In some experiments tosyl-lysine chloromethyl ketone (TLCK) or tunicamycin were added at the concentrations given in the text $20 \mathrm{~min}$ before the radioactive amino acid was added. For pulse-chase experiments, essentially the same procedure was used, except that labelled mycelium was chased with unlabelled methionine $(20 \mathrm{mM})$ plus cysteine $(20 \mathrm{mM})$ at a 4000 fold excess for the times given in the text.

Labelled mycelia were collected on Millipore filters, washed with cold distilled water, and comminuted under liquid nitrogen. The ground mycelium was shaken for $20 \mathrm{~min}$ with 5 vols of lysis buffer $\left(1.1^{\circ}{ }_{0}, v / v\right.$, Triton $\mathrm{X}-100,100 \mathrm{~mm}-\mathrm{Tris} / \mathrm{HCl}, \mathrm{pH} 7.8,10 \mathrm{~mm}-\mathrm{EDTA}$, I mM-PMSF, 0.1 mM-aprotinin, 0.02 mM-TLCK and 0.02 mM-leupeptin) at 4 " $\mathrm{C}$. Following clarification $(8000 \mathrm{~g}, 10 \mathrm{~min})$ supernatants were analysed by immunoprecipitation and by SDS-PAGE as described below. Proteins secreted into growth media were precipitated by incubating overnight at $-20^{\circ} \mathrm{C}$ with 3 vols $0 \cdot 1 \mathrm{M}$-ammonium acetate in methanol containing $1 \mathrm{~mm}$-PMSF. Proteins were collected by centrifugation $(10000 \mathrm{~g}, 10 \mathrm{~min})$ and redissolved in water.

Extraction procedures for $R N A$. Total RNA was extracted from small fungal samples using guanidine. $\mathrm{HCl}$. Infection structures (appressoria) were induced by germinating conidia in yeast extract medium (YEM) $(0.0125 \%)$ on glass Petri dishes as described previously (St Leger et al., 1989a). RNA was extracted after pouring off the YEM supernatant and adding $2.5 \mathrm{ml}$ of homogenizing buffer $(7.5 \mathrm{M}$ - guanidine. $\mathrm{HCl}, \quad 0 \cdot 1 \%$ Sarkosyl, $0.1 \mathrm{~m}-2$-mercaptoethanol, $10 \mathrm{~mm}-$ EDTA, $50 \mathrm{~mm}$-sodium citrate, $\mathrm{pH} 7$ ). Adhering germlings were scraped off and the buffer was then transferred sequentially to five other dishes. The mycelia from 30 dishes were pooled and homogenized by mixing in a vortex for $5 \mathrm{~min}$ with acid-washed glass beads $(1 \mathrm{~g}$; $<0.3 \mathrm{~mm}$ diam.). Following centrifugation, supernatants were heated at $65^{\circ} \mathrm{C}$ for $5 \mathrm{~min}$, extracted with phenol/chloroform and the RNA was precipitated with ethanol (Maniatis et al., 1982). After dissolving in water, some samples were treated with RNAase A (overnight) or DNAase $I(1 \mathrm{~h})$ at $0.1 \mathrm{mg} \mathrm{m}{ }^{-1}$ in the presence of $10 \mathrm{mM}-\mathrm{MgCl}_{2}$. Treated extracts were processed for dot-blot analysis as described below.

Washed conidia $(400 \mathrm{mg}$ ) harvested from $10 \mathrm{~d}$ SDA cultures (St Leger et al., 1989a), acid-washed glass beads $(1200 \mathrm{mg})(<0.3 \mathrm{~mm}$ diam.) and liquid nitrogen were placed in a $50 \mathrm{ml}$ centrifuge tube and vortexed for five periods of $5 \mathrm{~min}$ each, with renewal of liquid nitrogen as needed. Rapidly, before the contents of the tube thawed, the fractured conidia and glass were suspended in $5 \mathrm{ml}$ of homogenization buffer. All subsequent steps were as described for germlings.

Preparation and translation of poly $\left(\mathrm{A}^{+}\right) R N A$. Poly $\left(\mathrm{A}^{+}\right) \mathrm{RNA}$ was isolated from finely comminuted frozen mycelium by extracting with phenol/chloroform, precipitating the total RNA with ethanol, and isolating the poly $\left(\mathrm{A}^{+}\right) \mathrm{RNA}$ using oligo(dT) chromatography (Maniatis et al., 1982). Poly $\left(\mathrm{A}^{+}\right) \mathrm{RNA}$ was dissolved in sterile water, the solution divided into aliquots and stored at $-70^{\circ} \mathrm{C}$ until used. Poly $\left(\mathrm{A}^{+}\right) \mathrm{RNA}$ was translated in a rabbit reticulocyte cell-free translation system. Normally, $1 \mu \mathrm{g}$ poly $\left(\mathrm{A}^{+}\right)$RNA was translated in $40 \mu \mathrm{l}$ of solution containing $35 \mu \mathrm{l}$ of nuclease-treated rabbit reticulocyte lysate (Promega), 1 unit of RNAasin (Promega) $\mu^{-1}$, a mixture of unlabelled amino acids minus methionine $(25 \mu \mathrm{M}$ final concentration) and $1.5 \mu \mathrm{Ci}$ $\left.(55 \mathrm{kBq}){ }^{35} \mathrm{~S}\right]$ methionine (Amersham) $\mu \mathrm{l}^{-1}$ for $1 \mathrm{~h}$ at $30^{\circ} \mathrm{C}$.

Immunoprecipitations. Translation products were analysed by immunoprecipitation as described by Anderson \& Blobel (1983) with modifications. Samples $(10 \mu 1)$ of the translation mixture were added to 20 vols of immunoprecipitation buffer $(1 \%$, w/v, skimmed milk, $1 \cdot 1 \%$ Triton X-100, $100 \mathrm{~mm}$-Tris/HCl, $\mathrm{pH} 7 \cdot 8,100 \mathrm{~mm}-\mathrm{NaCl}, 10 \mathrm{~mm}$-EDTA, $1 \mathrm{~mm}$-PMSF, $0.1 \mathrm{~mm}$-aprotinin, $0.02 \mathrm{~mm}$-TLCK and $0.02 \mathrm{~mm}$-leupeptin) and incubated sequentially for $1 \mathrm{~h}$ each with $10 \mu \mathrm{l}$ of pre-immune serum and $30 \mu \mathrm{l}$ of a $1: 1(\mathrm{w} / \mathrm{v})$ suspension of protein A-Sepharose (Sigma) and immunoprecipitation buffer at $4{ }^{\circ} \mathrm{C}$. The samples were spun for $2 \mathrm{~min}$ in a microcentrifuge and the supernatants incubated sequentially for $\mathrm{I}$ h each with $\mathrm{I} \mu \mathrm{l}$ of rabbit polyclonal antisera specific for Prl (St Leger et al., 1989a) and $30 \mu$ of the protein A-Sepharose suspension. The Sepharose beads were washed extensively in the immunoprecipitation buffer, minus the skimmed milk, followed by a wash in similar buffer, minus detergents. Prl was eluted from the beads by boiling in SDS sample buffer (Laemmli, 1970) for $5 \mathrm{~min}$ and analysed by SDS-PAGE and autoradiography (St Leger et al., 1989a). The same procedure was used for immunoprecipitation experiments on labelled mycelial proteins. Samples $(10 \mu 1)$ of cell lysate in lysis buffer or growth media were added to 20 vols of immunoprecipitation buffer before proceeding as above.

Immunoblotting. Proteins, denatured by boiling for $10 \mathrm{~min}$, were placed in $1 \mu \mathrm{l}$ aliquots onto nitrocellulose pre-wetted with $10 \mathrm{~mm}$-Trisbuffered saline $(\mathrm{pH} 7 \cdot 4 ; 150 \mathrm{~mm}-\mathrm{NaCl})$. Blots probed with anti-Prl serum were developed with alkaline phosphatase coupled antibody to rabbit IgG according to the ProtoBlot Western blot AP system technical manual (Promega) except that $1 \%$ skimmed milk powder was used as a blocking agent.

Synthesis of subtracted complementary DNA (cDNA) probes. Large scale synthesis of single-stranded cDNA was done using $30 \mu \mathrm{g}$ of purified poly $\left(\mathrm{A}^{+}\right)$RNA from $2 \mathrm{~h}$ minimal medium cultures $(0.01 \%$ 
$\mathrm{KH}_{2} \mathrm{PO}_{4}, \quad 0.005 \% \mathrm{MgSO}_{4}$, without carbon or nitrogen source) as template and using random primers as described by Sambrook $e t$ al. (1989). Radiolabelled cDNAs for probes were synthesized by replacing the unlabelled dCTP with $\left[\alpha^{-32} \mathrm{P}\right] \mathrm{dCTP}\left[3000 \mathrm{Ci} \mathrm{mmol}^{-1}(111 \mathrm{TBq}\right.$ $\left.\mathrm{mmol}^{-1}\right)$; New England Nuclear] at $2 \mathrm{Ci} \mathrm{ml}^{-1}\left(74 \mathrm{kBq} \mathrm{ml}^{-1}\right)$. After incubation at $37^{\circ} \mathrm{C}$ for $1 \mathrm{~h}$, the reaction was stopped by the addition of $20 \mu 10.2 \mathrm{M}$-EDTA, and the RNA was hydrolysed by the addition of $25 \mu \mathrm{l}$ of $1 \mathrm{M}-\mathrm{NaOH}$ and incubation for $30 \mathrm{~min}$ at $70^{\circ} \mathrm{C}$. After neutralization the unincorporated label was removed by centrifugal Sephadex G-50 chromatography (Maniatis et al., 1982). Singlestranded radiolabelled cDNA $(13 \mu \mathrm{g})$ was subtracted, to obtain unique sequences, with $100 \mu \mathrm{g}$ poly $\left(\mathrm{A}^{+}\right) \mathrm{RNA}$ from $3 \mathrm{~d}$ SDB cultures using a hybridization technique employing photoactivatable biotin and phenol extraction essentially by the method of Sive \& St John (1988), except that the volumes of all components in the reaction were increased by a factor of five to match the amount of cDNA. Three similar cycles of hybridization were completed to drive the subtraction hybridization to completion.

Analysis of the subtracted cDNA was by hybridization/selection (Goldberg et al., 1979). The subtracted cDNA was immobilized onto a $0.5 \mathrm{~cm}^{2}$ disc of freshly diazotized (diazobenzyloxymethyl, DBM) Whatman 540 paper (Williams et al., 1979). The disc was hybridized for $6 \mathrm{~h}$ at $37^{\circ} \mathrm{C}$ with $0.15 \mu \mathrm{g}$ poly $\left(\mathrm{A}^{+}\right) \mathrm{RNA}$ from $1 \mathrm{~h}$ minimal medium cultures in $50 \mu \mathrm{l}$ of buffer $(50 \%, \mathrm{v} / \mathrm{v}$, formamide, $0.8 \mathrm{M}-\mathrm{NaCl}, 0.2 \%$ SDS, 2 mM-EDTA, 20 mM-PIPES, pH 6.4). The disc was washed at $37^{\circ} \mathrm{C}$ four times for $20 \mathrm{~min}$ each with $200 \mathrm{ml} 20 \mathrm{~mm}-\mathrm{NaCl}, 8 \mathrm{~mm}$ trisodium citrate, $\mathrm{pH} 7.0(1 \times \mathrm{SSC}), 50 \%(\mathrm{v} / \mathrm{v})$ formamide and $0.2 \%$ SDS and twice in $200 \mathrm{ml}$ of $2 \times$ SSC. RNA was eluted from the filters by shaking in $100 \mu \mathrm{l}$ of extraction buffer ( $20 \mathrm{~mm}$-PIPES, pH $6.4,0.5 \%$ SDS, $1 \mathrm{~mm}$-EDTA and $90 \%, \mathrm{v} / \mathrm{v}$, formamide). The eluates from 10 similar hybridization cycles using the same disc (which had been recycled through an alkaloid elution step between hybridizations) were combined and diluted with 2 vols of water, wheatgerm tRNA was added to $20 \mu \mathrm{g} \mathrm{ml}^{-1}$ and the RNA was precipitated with ethanol. Samples were reprecipitated from ethanol and washed in $70 \%(\mathrm{v} / \mathrm{v})$ ethanol. After dissolving in water, samples were translated using rabbit reticulocyte lysate.

RNA dot-blots. Dot-blots were done by the procedure of Thompson et al. (1983). RNA, denatured with $6 \%(\mathrm{v} / \mathrm{v})$ formalin in $20 \mathrm{mM}$-sodium phosphate, $\mathrm{pH} 6.8$, at $55^{\circ} \mathrm{C}$ was placed in $2 \mu \mathrm{l}$ aliquots on pre-wetted (water, then $2 \times \mathrm{SSC}$ ) nitrocellulose membranes (BA85: Schleicher and Schuell). Following baking at $80^{\circ} \mathrm{C}$ under vacuum, hybridization was done with the subtracted $\left[{ }^{32} \mathrm{P}\right] \mathrm{cDNA}$ probe at $42^{\circ} \mathrm{C}$ for $15 \mathrm{~h}$ in $50 \%(\mathrm{v} / \mathrm{v})$ formamide, $3 \times \mathrm{SSC}, 1 \times$ Denhardt's medium, $200 \mu \mathrm{g}$ yeast RNA ml ${ }^{-1}$ and $20 \mu \mathrm{g}$ denatured salmon sperm RNA ml-1. Blots were washed sequentially in $2 \times \operatorname{SSC}\left(2 \times 10 \mathrm{~min}, 23^{\circ} \mathrm{C}\right), 0 \cdot 1 \times \mathrm{SSC}$ plus $0.1 \% \operatorname{SDS}\left(3 \times 20 \mathrm{~min}, 50^{\circ} \mathrm{C}\right)$ and rinsed rapidly three times in $0.1 \times$ SSC plus $0.1 \%$ SDS at $23{ }^{\circ} \mathrm{C}$, and three times in $0.1 \times$ SSC before analysis by autoradiography.

Miscellaneous. Prl activity toward succinyl-(alanine) $)_{2}$-prolinephenyl-alanine-p-nitroanilide [Suc-(Ala) ${ }_{2}$-Pro-Phe- $p$ NA] was assayed as described by St Leger $e t$ al. (1987b). Clean samples of cuticle from 3-d-old fifth instar Manduca sexta larvae were prepared as described previously (St Leger et al., 1988b).

Chemicals. Except where indicated in the text, all chemicals were from Sigma.

\section{Results}

\section{Production of Prl during nutrient deprivation}

Mycelia of five species of entomopathogenic fungi, growing rapidly in SDB cultures, were transferred to media in which growth was limited by carbon and nitrogen deprivation (Table 1). In response, these fungi produced activities against the $\operatorname{Pr} 1$ substrate (Suc-(Ala) $2_{2}^{-}$ Pro-Phe-pNA (Table 1). As reported previously for Metarhizium (St Leger et al., 1988b), enzyme levels were frequently enhanced in cultures supplied with Manduca cuticle or other insoluble protein or non-protein (cellulose) polymers at levels insufficient to produce catabolite repression. However, in each case, production of protease was repressed in SDB or when $N$-acetylglucosamine $(1 \%, \mathrm{w} / \mathrm{v})$ was added to medium containing cuticle,

Table 1. Protease production by five species of entomopathogenic fungi $8 \mathrm{~h}$ after transfer of growing mycelium to nutrient-rich or nutrient-limiting conditions

Protease activity was measured spectrophotometrically with Suc-(Ala) $)_{2}$-Pro-Phe-pNA as the substrate. Results represent mean protease activity $\left(\mathrm{nmol} p \mathrm{NA} \mathrm{ml}^{-1} \mathrm{~min}^{-1}\right)$ for three replicates $\pm \mathrm{SD}$. The results are representative of two similar experiments.

\begin{tabular}{|c|c|c|c|c|c|}
\hline Medium* & M. anisopliae & $V$. lecanii & B. bassiana & P. farinosus & $T$. niveum \\
\hline$-\mathrm{CN}$ & $32 \cdot 7 \pm 4.53$ & $24 \cdot 7 \pm 3.94$ & $20.9 \pm 3.57$ & $6 \cdot 3 \pm 0.84$ & $21 \cdot 6 \pm 2 \cdot 6$ \\
\hline $\begin{array}{l}-\mathrm{CN}+\text { Manduca cuticle } \\
(0.5 \%)\end{array}$ & $75 \cdot 2 \pm 6 \cdot 82$ & $36 \cdot 2 \pm 3 \cdot 13$ & $30 \cdot 3 \pm 2 \cdot 85$ & $10 \cdot 41 \pm 1.42$ & $29 \cdot 4 \pm 1$ \\
\hline$-\mathrm{CN}+\operatorname{chitin}(0.5 \%)$ & $51 \cdot 1 \pm 4 \cdot 31$ & $32 \cdot 8 \pm 4 \cdot 30$ & $34 \cdot 1 \pm 4 \cdot 31$ & $7.9 \pm 0.38$ & $31 \cdot 8 \pm 3 \cdot 7$ \\
\hline$-\mathrm{CN}+$ cellulose $(0.5 \%) \dagger$ & $44 \cdot 3 \pm 5 \cdot 62$ & $28 \cdot 6 \pm 2.62$ & $29 \cdot 5 \pm 2 \cdot 65$ & $9 \cdot 19 \pm 0 \cdot 83$ & $38 \cdot 6 \pm 2 \cdot 4$ \\
\hline $\begin{array}{c}-\mathrm{CN}+\text { Manduca cuticle } \\
(0.5 \%)+\text { NAG }(1 \%)\end{array}$ & $0.2 \pm 0 \cdot 01$ & $2 \cdot 27 \pm 0 \cdot 13$ & $\overline{0}$ & 0 & $3.4 \pm 0 \cdot 54$ \\
\hline $\begin{array}{l}-\mathrm{CN}+\text { actinomycin } \mathrm{D} \\
\left(100 \mu \mathrm{g} \mathrm{ml}^{-1}\right)\end{array}$ & $8.6 \pm 0.81$ & $4 \cdot 38 \pm 0 \cdot 44$ & $7 \cdot 23 \pm 0 \cdot 23$ & 0 & $7 \cdot 38 \pm 0.85$ \\
\hline SDB & 0 & 0 & 0 & 0 & 0 \\
\hline
\end{tabular}

* - $\mathrm{CN}$, minimal medium $\left(0.01 \% \mathrm{~K} \mathrm{H}_{2} \mathrm{PO}_{4}, 0.005 \% \mathrm{MgSO}_{4}\right)$ without a carbon or nitrogen source. Except for $V$. lecanii $\left(23^{\circ} \mathrm{C}\right)$ and $\mathrm{B}$. bassiana $\left(25^{\circ} \mathrm{C}\right)$ isolates were incubated at $27^{\circ} \mathrm{C}$.

$\dagger$ Insoluble crystalline cellulose. 


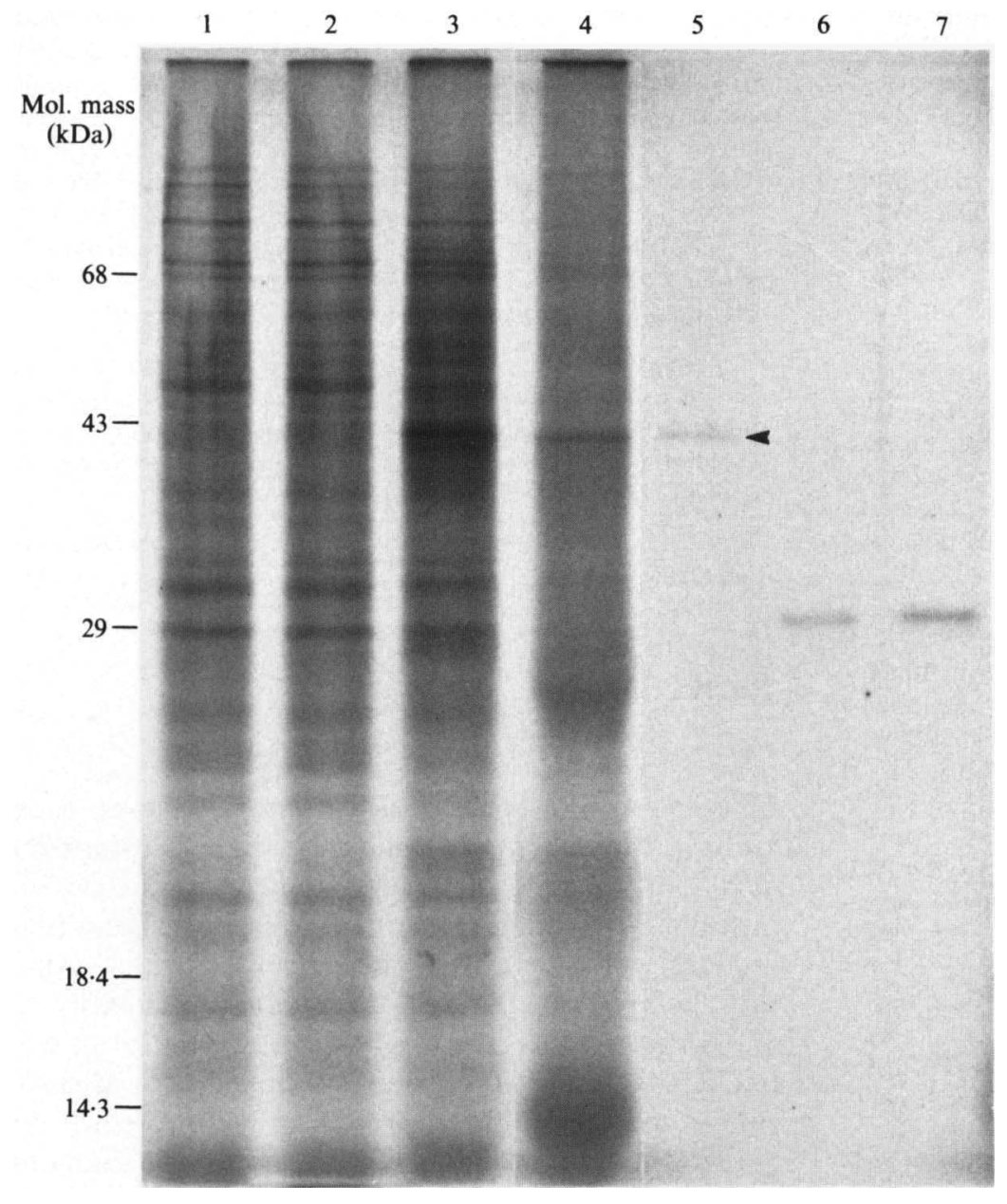

Fig. 1. Protein coding capacities of poly $\left(\mathrm{A}^{+}\right) \mathrm{RNA}$ from Metarhizium during production of $\mathrm{Pr}$. Poly$\left(A^{+}\right)$RNA was extracted from mycelia incubated in minimal medium for (lane 1) $0 \mathrm{~h}$ (mycelia taken directly from $1 \% \mathrm{NAG}$ /basal salts medium), (2) $0.5 \mathrm{~h}$, (3) $1 \mathrm{~h}$ and (4) $7 \mathrm{~h}$ and translated in the presence of $\left[{ }^{35} S\right]$ methionine; lanes 5,6 and 7 , translation products from poly $\left(\mathrm{A}^{+}\right) \mathrm{RNA}$ from $\mathrm{l} \mathrm{h}$ minimal medium cultures processed and immunoprecipitated with anti-Prl-bodies (5) and compared with immunoprecipitated samples of active $\operatorname{Prl}$ from culture filtrates of $2 \mathrm{~h}$ minimal medium cultures (6) and $2 \mathrm{~h}$ $0.5 \%$ chitin/basal salts medium cultures (7). The arrowhead indicates the position of the primary translation product of $\mathrm{Prl}$.

showing that repression overrides the enhancing effect of polymeric substrates. The production of extracellular proteases by starved mycelia apparently required de novo RNA synthesis as activities were reduced by the transcription inhibitor actinomycin D (Table 1).

Further studies on Metarhizium demonstrated that the source of fungal inocula influenced protease $(\operatorname{Pr} 1)$ release. The use of fungal inocula grown for $3 \mathrm{~d}$ on $2 \%$ (w/v) NAG/basal salts (St Leger et al., 1986a), a relatively poor growth medium (growth rate $1.5 \pm$ $0.31 \mathrm{mg}$ dry wt $\mathrm{ml}^{-1} \mathrm{~d}^{-1}$ ) but sufficient to repress $\operatorname{Prl}$ synthesis, resulted in the appearance of Prl within $1 \mathrm{~h}$ of transfer to minimal medium. By contrast, Prl activity was only apparent after $3 \mathrm{~h}$ using inocula from $32 \mathrm{~h} \mathrm{SDB}$ cultures (growth rate $3.97 \pm 0.53 \mathrm{mg}^{\mathrm{dry}} \mathrm{wt} \mathrm{ml}^{-1} \mathrm{~d}^{-1}$ ) or $3 \mathrm{~d}$ SDB cultures $\left(4 \cdot 5 \pm 0.43 \mathrm{mg}\right.$ dry wt $\left.\mathrm{ml}^{-1} \mathrm{~d}^{-1}\right)$. Prl activity $4 \mathrm{~h}$ post-transfer from $3 \mathrm{~d}$ SDB cultures or $4 \mathrm{~h}$ post-transfer from $3 \mathrm{~d}$ NAG cultures was $13.64 \pm$ $1.8 \mathrm{nmol} p \mathrm{NA} \mathrm{ml}^{-1} \mathrm{~min}^{-1}$ and $45.42 \pm 3.6 \mathrm{nmol} p \mathrm{NA}$ $\mathrm{ml}^{-1} \mathrm{~min}^{-1}$, respectively. Prl was not detected in Metarhizium growth media following transfer of cultures from SDB to fresh SDB, or after a heat-shock treatment $\left(55^{\circ} \mathrm{C}, 5 \mathrm{~min}\right)$. Thus the production of $\mathrm{Prl}$ is not a component of a stereotyped response to stress but part of an adjustment to altered growth conditions.

\section{Quantitative changes in the $m R N A$ production}

At various intervals during Prl production in nutrientdeprived media (without carbon and nitrogen source), poly $\left(\mathrm{A}^{+}\right) \mathrm{RNAs}$ were extracted and their protein-coding capacities were assessed in a cell-free rabbit reticulocyte translation system. The patterns observed with NAG medium and nutrient-deprived medium were very similar until $60 \mathrm{~min}$ post-transfer when there was a considerable induction of mRNA for a $41 \mathrm{kDa}$ protein (Fig. 1). The quality of poly $\left(\mathrm{A}^{+}\right) \mathrm{RNA}$ had deteriorated in mycelia harvested after several hours in nutrientdeprived conditions. Some of the bands became faint, broad or indistinct. However, the transcript for the $41 \mathrm{kDa}$ protein apparently retained its integrity better than most other transcripts (Fig. 1, lane 4), suggesting 


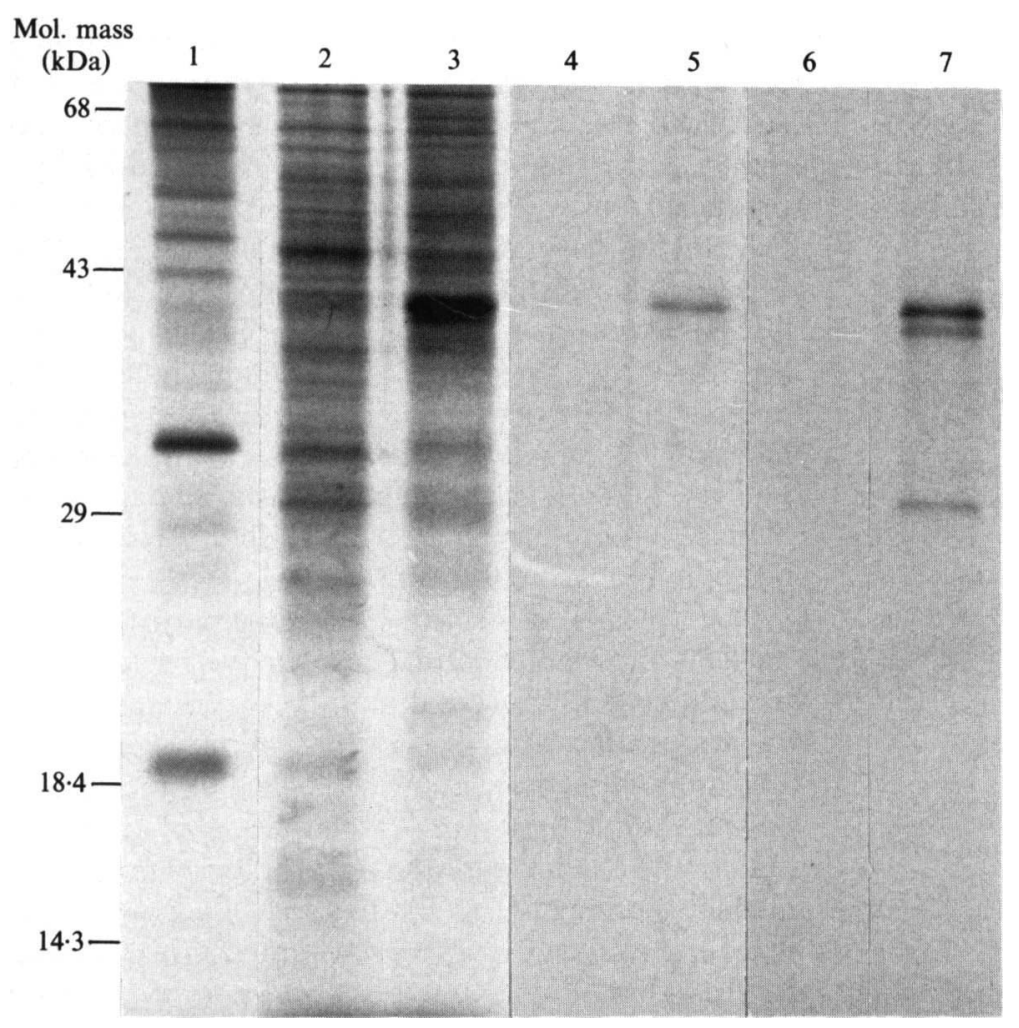

Fig. 2. Changes in the mRNA population during nutrient deprivation. Protein coding capacities of poly $\left(\mathrm{A}^{+}\right) \mathrm{RNA}$ isolated from Metarhizium from NAG cultures (lane 2) and from cultures transferred from $\mathrm{NAG} /$ basal salts medium for $2 \mathrm{~h}$ (lane 3). Immunoprecipitation of translation products from $3 \mathrm{~d}$ NAG (lane 4) and $1 \mathrm{~h}$ minimal medium cultures (lanes 5 and 6). Translation products were processed and immunoprecipitated with anti-Prl-serum as described in the text with the exception of the sample in lane 6 which was immunoprecipitated after adding $5 \mu \mathrm{g} \operatorname{Pr} 1$. Using the procedure described in Methods, poly $\left(\mathrm{A}^{+}\right) \mathrm{RNA}$ isolated from $1 \mathrm{~h}$ minimal medium cultures was hybridized to diazotized paper discs bearing $c D N A$ which had been constructed from the same poly $\left(\mathrm{A}^{+}\right) \mathrm{RNA}$ and subsequently subtracted with poly $\left(\mathrm{A}^{+}\right) \mathrm{RNA}$ isolated from $3 \mathrm{~d}$ NAG cultures. RNA was eluted from the discs and translated (lane 7). Lane 1 shows translation products from Brome Mosaic Virus RNA used as a positive control of the translation system.

maintained synthesis and/or that it is a peculiarly stable species. Its protein product comigrated on SDS-polyacrylamide gels with the single protein $(41 \mathrm{kDa})$ precipitated from translation mixtures by anti-Prl-serum, and which was likewise absent in mycelia grown in nutrientrich medium (Fig. 2). Prl $(5 \mu \mathrm{g})$ added to the translation mixture before addition of the antibody effectively competed with the $41 \mathrm{kDa}$ translation product, strongly suggesting that this protein is immunologically similar to the mature Pr1 from Metarhizium in spite of the $11 \mathrm{kDa}$ difference in molecular mass (Fig. 1).

To clarify further changes in the mRNA population, mRNA enriched for transcripts present only in the nutrient-deprived mycelia was analysed. Fig. 2 (lane 7) shows a typical autofluorogram of the in vitro synthesized polypeptides obtained from hybrid selected mRNA. By this method it was possible to detect the de novo appearance of three major translatable mRNA species for polypeptides of molecular mass $41,40 \cdot 2$ and $29 \cdot 8 \mathrm{kDa}$. Anti-Pr1 serum selectively precipitated only the $41 \mathrm{kDa}$ species indicating that the 40.2 and $29.8 \mathrm{kDa}$ proteins are immunologically unrelated to $\operatorname{Prl}$.

To analyse further whether starvation-induced mRNA species involved transcription, dot-blot analysis of total RNA was done using the subtraction $\left[{ }^{32} \mathrm{P}\right] \mathrm{cDNA}$ probe. Within $1 \mathrm{~h}$ of the transfer of mycelium from NAG medium, starvation-specific mRNA transcripts were detectable and the level increased sharply over the next $4 \mathrm{~h}$ (Fig. 3). Treatment of samples with RNAase entirely eliminated binding of the probe further indicating that de novo RNA synthesis was involved. Immunoblot analysis confirmed that the corresponding increase in $\operatorname{Prl}$ activity represented a true increase in the amount of Prl protein in the medium (Fig. 3). Actinomycin D was used at a concentration $\left(100 \mu \mathrm{g} \mathrm{ml}^{-1}\right)$ which massively reduces detectable RNA synthesis in Metarhizium ( $\mathrm{St}$ Leger et al., 1989b). Addition of actinomycin D at the beginning of starvation inhibited the de novo formation of unique mRNA and the formation of $\operatorname{Pr} 1$ (Fig. 3). These results suggest some regulation of gene expression exerted at transcription during starvation. We wondered, however, whether these RNAs could be packaged into spores, perhaps stored for future use. As shown in Fig. 4, total RNA from fractured spores contained only low levels of mRNA species recognized by the subtraction $\left.{ }^{32} \mathrm{P}\right] \mathrm{cDNA}$ probe. By contrast, high levels of messenger were present in germlings forming appressoria, which correlated with Prl production.

\section{Precursors and processing of Pr1.}

$\left[{ }^{35} \mathrm{~S}\right]$ Methionine incorporation into proteins was studied in mycelia transferred to nutrient-deprived medium. Pulse-labelling mycelia for $10 \mathrm{~min}, 3 \mathrm{~h}$ post-transfer to 

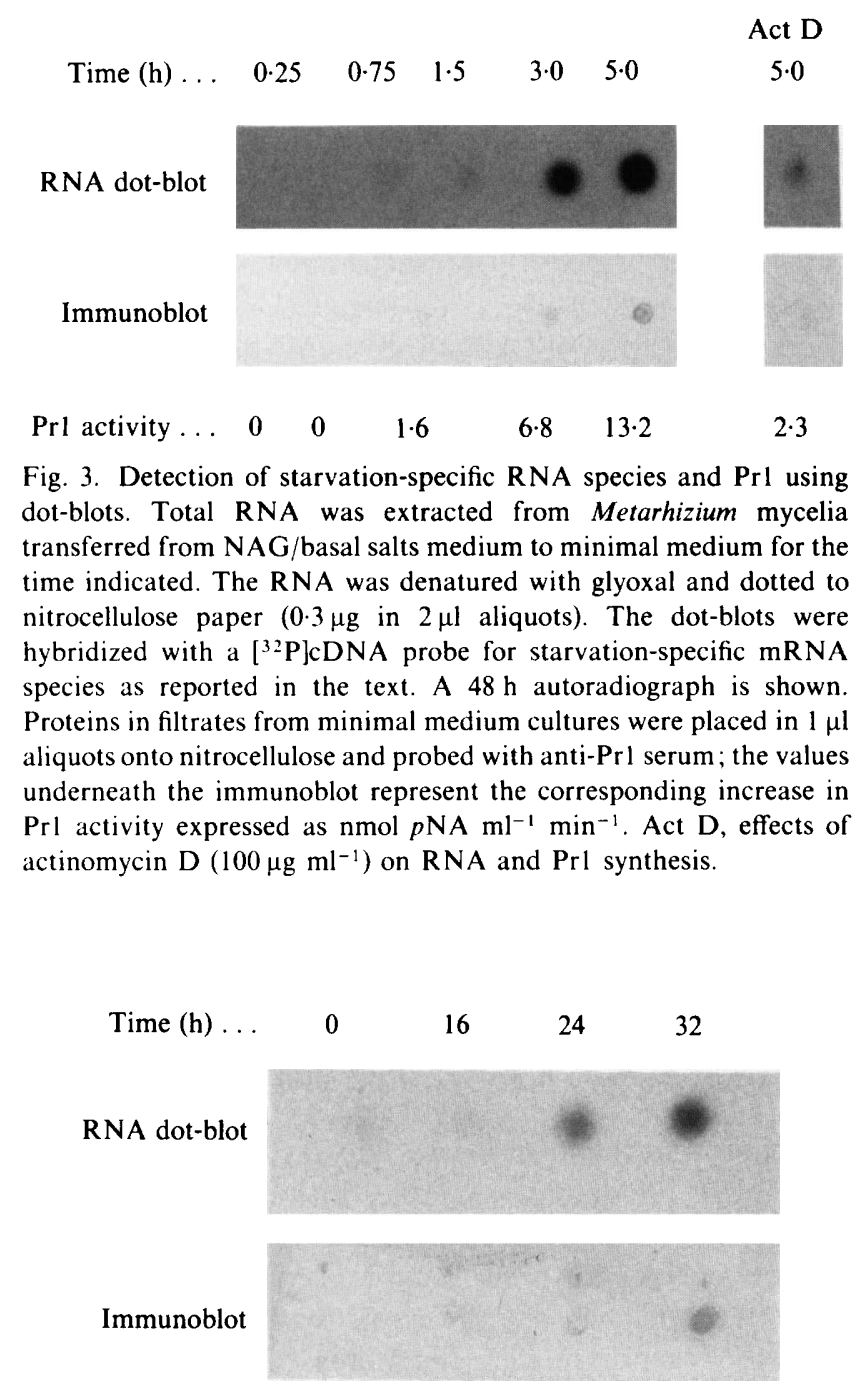

Fig. 4. Detection of starvation-specific RNA species and Prl during differentiation of appressoria. Total RNA was extracted from germlings differentiating for the time indicated $(0$, ungerminated conidia), denatured and dotted to nitrocellulose paper $(0 \cdot 2 \mu \mathrm{g}$ in $4 \mu \mathrm{l}$ aliquots). The dot-blots were hybridized with a $\left.{ }^{32} \mathrm{P}\right] \mathrm{cDNA}$ probe for starvation-specific mRNA species. A $72 \mathrm{~h}$ autoradiograph is shown. Proteins extracted from conidia or germlings in lysis buffer were placed in $1 \mu 1$ aliquots on nitrocellulose filters and probed with anti-Prl serum.

minimal medium, allowed resolution of more than 30 proteins, and immunoprecipitation of detectable levels of 41 and $40.8 \mathrm{kDa}$ proteins as well as mature extracellular Prl (Fig. 5). Prl added to the mycelial lysate before addition of the antibody effectively competed with each of these proteins. We assume, therefore, from the identity of molecular masses that the $41 \mathrm{kDa}$ protein represents the primary translation product previously identified by in vitro translation. In two out of four replicates, labelling of mycelia for longer than $5 \mathrm{~min}$ revealed a faint low molecular mass band $(26.5 \mathrm{kDa})$ that may or may not be related to $\operatorname{Pr} 1$.
The 41 and $40.8 \mathrm{kDa}$ precursors were present in very low amounts as compared with the mature protease. This suggested that the precursors are rapidly processed so that the fraction of labelled Prl represented by the precursor remains low. Consistent with this, labelling of mycelia for longer than 10 min revealed only the $41 \mathrm{kDa}$ precursor, suggesting that the fraction of total label in the $40.8 \mathrm{kDa}$ precursor was almost zero. This hypothesis was confirmed by a pulse-chase experiment. After a $10 \mathrm{~min}$ chase with cold methionine plus cysteine the fraction of labelled Prl represented by the precursors was greatly reduced while levels of mature extracellular Prl were almost unaffected (Fig. 5). Neither precursor was detectable in growth media.

The time taken for mycelia to process an amino acid nutrient into mature extracellular $\operatorname{Pr} 1$ was determined by precipitating Prl secreted into the supernatant medium at various times after the addition of $\left[{ }^{35}\right.$ S $]$ methionine to $3 \mathrm{~h}$ minimal media cultures. Labelled extracellular Prl appeared first 5-10 min after addition of the labelled amino acid and increased sharply for the 20 min duration of the experiment (Fig. 5). The Prl bands were cut-out and their radioactivities were counted in a scintillation counter. The transit time from addition of label to the appearance of extracellular $\operatorname{Prl}$ was $6.5-7.2 \mathrm{~min}$, as calculated from three similar pulse-chase experiments by plotting the counts incorporated into the Prl bands versus time and extrapolating to zero counts.

Production of active Prl was reduced by $63 \%$ after pre-incubation $(3 \mathrm{~h})$ with tunicamycin $\left(100 \mu \mathrm{g} \mathrm{ml}^{-1}\right)$, indicating that glycosylation reactions are involved in processing of $\operatorname{Prl}$; the relative molecular mass of the mature protease was unaffected by tunicamycin, showing a low level of $\operatorname{Pr} 1$ glycosylation.

The results described above suggest that a precursor of high molecular mass is processed down to the low molecular mass active enzyme, presumably by selective proteolytic cleavage. To test for the involvement of the trypsin-like Metarhizium enzyme Pr2 (St Leger et al., $1987 \mathrm{~h})$, we pre-incubated mycelia $(1 \mathrm{~h})$ with the specific $\operatorname{Pr} 2$ inhibitor TLCK. This inhibitor blocks formation of appressoria indicating that it can enter mycelium (unpublished data). Nevertheless, the inhibitor had no effect on production and apparent molecular mass of the Prl protein.

\section{Discussion}

The appearance of $\operatorname{Prl}$ is accompanied by a similar change in the prevalence of translatable Prl transcripts; thus the formation of translatable mRNA is required for the increased rate of Prl synthesis. This information, coupled with the lack of transcripts in ungerminated 


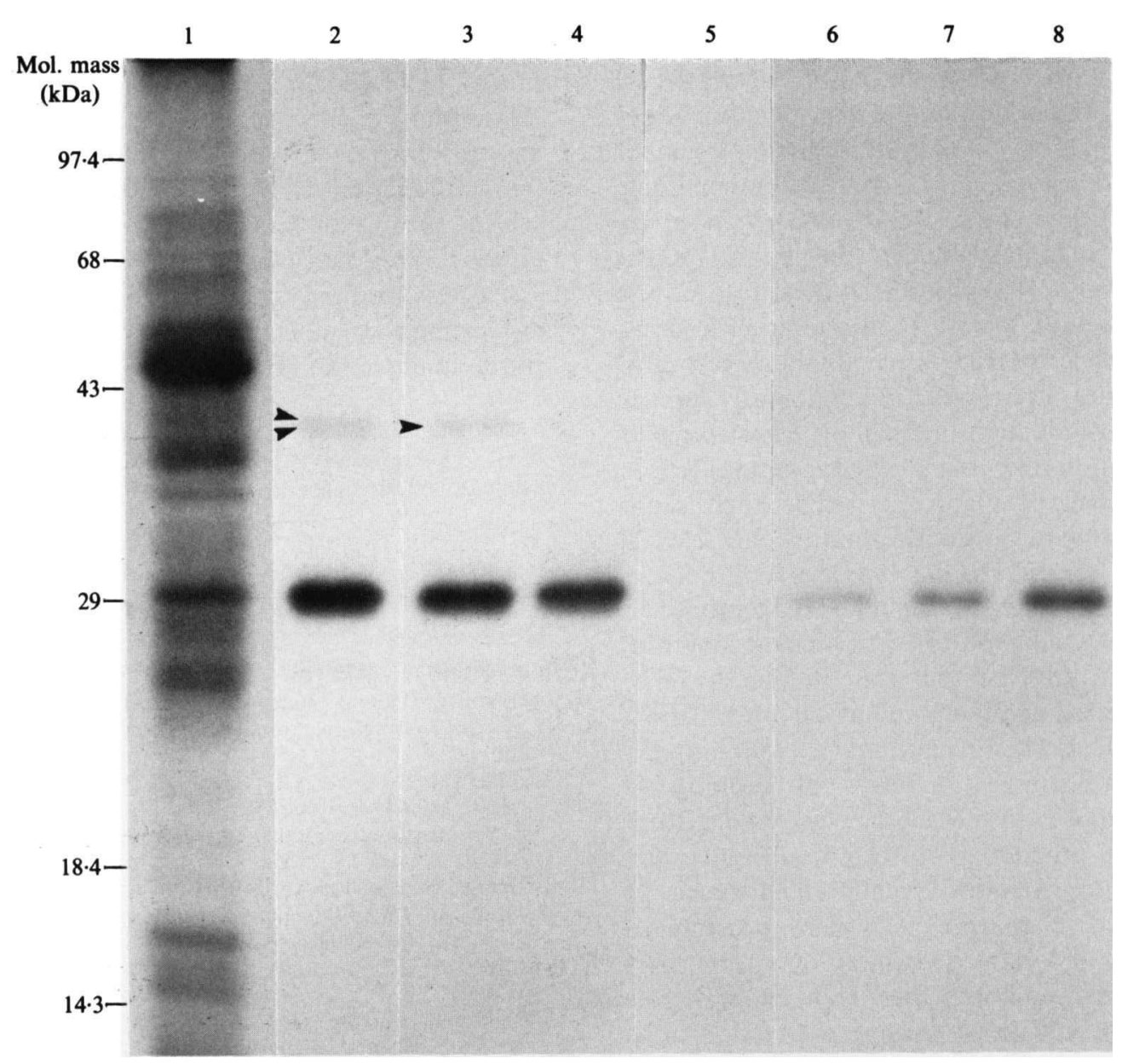

Fig. 5. Pulse-chase analysis on the accumulation of $\operatorname{Pr} 1$ and $\operatorname{Prl}$ precursors by Metarhizium in $3 \mathrm{~h}$ minimal medium cultures. Mycelia were pulse-labelled with $\left.{ }^{35} \mathrm{~S}\right]$ methionine $\left[50 \mu \mathrm{Ci} \mathrm{ml}^{-1}\left(1.85 \mathrm{MBq} \mathrm{ml}^{-1}\right)\right]$ for $10 \mathrm{~min}$. Lane 1, total labelled proteins extracted from mycelia. Lanes 2-4, radioactivity chased with unlabelled methionine for $0 \mathrm{~min}$ (control) (lane 2), $5 \mathrm{~min}$ (lane 3) or $10 \mathrm{~min}$ (lane 4) and cells processed and immunoprecipitated with anti-Prl-serum. The arrowheads indicate two bands ( 41 and $40.8 \mathrm{kDa})$ in lane 2 and one band in lane 3. Lanes 5-8, time course of secretion of Prl following pulse-labelling with [ $\left.{ }^{35} \mathrm{~S}\right]$ methionine for $5 \mathrm{~min}$ (lane 5), $10 \mathrm{~min}$ (lane 6), $15 \mathrm{~min}$ (lane 7) or $20 \mathrm{~min}$ (lane 8); the culture supernatant was precipitated with ammonium acetate in methanol and re-dissolved precipitates immunoprecipitated with anti-Prl-serum.

conidia, and our information that inhibition of RNA synthesis inhibits the synthesis of starvation-induced transcripts, strongly suggests that the regulation of synthesis of starvation-induced proteins is at the level of transcription. Nevertheless, since the primary translation product of $\operatorname{Prl}$ is $11 \mathrm{kDa}$ larger than the mature protease, substantial post-translational processing must be involved in production of active enzyme. Detection of a $40.8 \mathrm{kDa}$ precursor suggests this may involve multiple steps. High molecular mass proenzymes are the norm among the extracellular proteases of bacteria (Kessler \& Safrin, 1988). They may also be common to proteases of fungi as attested to by the recent demonstration of a very large precursor $(76 \mathrm{kDa})$ for a vacuolar protease $(31 \mathrm{kDa})$ in Saccharomyces cerevisiae (Moehle et al., 1989). This contrasts sharply with the primary translation products of fungal cutinase and pectinase which are just $2-3 \mathrm{kDa}$ larger than the mature extracellular enzyme (Flurkey \& Kolattukudy, 1981; DeLorenzo et al., 1987). The function(s) of the large precursor polypeptides are not known, but presumably they keep the cell-associated enzyme inactive preventing proteolysis of cell constituents. Consistent with this, $\operatorname{Pr} 1$ is very active against components of Metarhizium mycelium after partial disruption of the cell by heating at $85^{\circ} \mathrm{C}$ (unpublished data).

Production of $\operatorname{Pr} 1$ was brought about by carbon and nitrogen derepression alone. Rapid growth in nutrientrich media (e.g. SDB) delayed subsequent Prl production, as compared with a poorer growth medium, after transfer to nutrient deprivation, suggesting that depletion of accumulated nutrient reserves linked to reduced 
growth rate may be the non-specific signal for Prl production. The most rapid initiation of $\operatorname{Prl}$ synthesis, which occurred within 45-60 min of transfer from NAG medium, is comparable temporally with induction of Metarhizium chitinase by chitin degradation products (30-60 min) (St Leger et al., 1986 b) and of Fusarium cutinase by cutin monomer inducers (30-45 min) (Woloshuck \& Kolattukudy, 1986). While cutinase transcripts, however, are detectable within 15 min after addition of the inducers, $\operatorname{Prl}$ transcripts were not observed until 45 min post-transfer. Prl production apparently catches up with cutinase production in the short transit time of 6.5-7.2 min from uptake of labelled amino acid to extracellular release of mature enzyme. Such rapid secretion implies that in spite of the binding of Pr1 to cell wall components (Goettel et al., 1989), a large component of the enzyme secreted through the cell membrane is not retained by the cell wall for a significant length of time. It therefore appears that the 'tighter' form of control for cutinase, involving induction by substrate components (Woloshuck \& Kolattukudy, 1986), imparts no significant advantage in terms of rapidity of regulation compared with the 'looser', less precise form of control of $\mathrm{Prl}$ production by catabolite repression alone. The difference in mode of regulation must relate to the roles of the two enzymes. Cutinase possesses a narrow specificity and, as it is required only for a brief period during penetration of the host plant cell wall, it is energetically conservative for enzyme production to be subject to a high degree of regulatory control mediated by the cutin component of the wall. By contrast, the broadspectrum proteolytic activity of Prl (St Leger et al., $1987 b$ ) may have biological functions before and after host cuticle is breached. Its activity will allow utilization of many insoluble substrates during nutrient deprivation, whether the fungus is living as a saprophyte or pathogen.

Prl transcript was the major mRNA species novel to starvation-induced cultures, indicating the comparative importance of Prl in providing nutrients during starvation conditions as compared with other depolymerases. Other workers have used the two-dimensional electrophoretic technique of O'Farrell (1975) to obtain greater sensitivity of identification of novel proteins. However, the very basic nature of $\operatorname{Prl}$ (pI about 10.5 ; it migrates into the region of the cathode), and the sometimes confusing and contradictory results obtained trying to identify novel proteins (Lovett, 1987), led us to use the alternative technique of select-hybridization to identify novel polypeptides. We assume the three transcripts detected represent completely novel mRNA species; even large changes in the abundance of other transcripts should not have been detected because of the exhaustive subtraction hybridization that was done. The two Prlunrelated polypeptides were not identified but Metarhi- zium produces a wide range of extracellular hydrolases in nutritionally poor media (St Leger et al., 1986a).

In summary, there appears to be regulation of $\mathrm{Prl}$ gene expression exerted at transcription during starvation, with production of a high molecular mass precursor which is rapidly processed to active extracellular enzyme. Proteases of several other important entomopathogens are also produced during nutrient deprivation, suggesting our results may have widespread implications in the understanding of fungal pathogenesis of insects.

The authors are grateful for the technical assistance of Mr David Frank. This work was supported in part by a grant (89-37263-4463) from the USDA Competitive Research Grants Office.

\section{References}

ANDERSON, D. J. \& Blobel, G. (1983). Immunoprecipitation of proteins from cell-free translations. Methods in Enzymology 96, 111 120.

Delorenzo, G., Salir, G., Degra, Z., D’Oridio, R. \& Cervone, F. (1987). Induction of extracellular polygalacturonase and its mRNA in the phytopathogenic fungus Fusarium moniliforme. Journal of General Microbiology 133, 3365-3373.

Flurkey, W. H. \& Kolattukudy, P. E. (1981). In vitro translation of cutinase mRNA: evidence for a precursor form of an extracellular fungal enzyme. Archives of Biochemistry and Biophysics 212, 154-161.

Goettel, M. S., St Leger, R. J., Rizzo, N. W., Staples, R. C \& ROBERTS, D. W. (1989). Ultrastructural localization of a cuticledegrading protease produced by the entomopathogenic fungus Metarhizium anisopliae during penetration of host (Manduca sexta) cuticle. Journal of General Microbiology 135, 2233-2239.

Goldberg, M. L., Lifton, R. P., Stark, G. R. \& Williams, J. G. (1979). Isolation of specific RNA's using DNA covalently linked to diazobenzyloxymethyl cellulose on paper. Methods in Enzymology 68, 207-220.

KeSSLER, E. \& SAFrin, M. (1988). Synthesis, processing and transport of Pseudomonas aeruginosa elastase. Journal of Bacteriology 170, $5241-5247$

LAEMmLI, U. K. (1970). Cleavage of structural proteins during the assembly of the head of bacteriophage T4. Nature, London 227,680 685 .

LovetT, J. S. (1987). The molecular biology of fungal development. In Plant-Microbe Interactions, Molecular and Genetic Perspectives, vol. 2, pp. 64-99. Edited by T. Kosuge \& E. W. Nester. New York: Macmillan.

Maniatis, T., Fritsch, E. F. \& Sambrook, J. (1982). Molecular Cloning: a Laboratory Manual, pp. 194-195. Cold Spring Harbor, NY: Cold Spring Harbor Laboratory.

Moehle, C. M., Dixon, C. K. \& Jones, G. W. (1989). Processing pathway for protease B of Saccharomyces cerevisiae. Journal of Cellular Biology 108, 309-324.

O'Farrell, P. H. (1975). High-resolution two-dimensional electrophoresis of proteins. Journal of Biological Chemistry 250, 4007-4021.

Sambrook, J., Fritsch, E. F. \& Maniatis, T. (1989). Molecular Cloning : a Laboratory Manual, 2nd edn., vol. 2, sect. 8. Cold Spring Harbor, NY: Cold Spring Harbor Laboratory.

St Leger, R. J., Charnley, A. K. \& Cooper, R. M. (1986a). Cuticledegrading enzymes of entomopathogenic fungi: synthesis in culture on cuticle. Journal of Inverterbrate Pathology 48, 85-95.

St Leger, R. J., Cooper, R. M. \& Charnley, A. K. (1986 b). Cuticledegrading enzymes of entomopathogenic fungi: regulation of production of chitinolytic enzymes. Journal of General Microbiology. 132, $1509-1517$. 
St Leger, R. J., Cooper, R. M. \& Charnley, A. K. (1987a). Production of cuticle-degrading enzymes by the entomopathogen Metarhizium anisopliae during infection of cuticles from Calliphora vomitoria and Manduca sexta. Journal of General Microbiology 133, 1371-1382.

St Leger, R. J., Charnley, A. K. \& CoOper, R. M. (1987b). Characterization of cuticle-degrading proteases produced by the entomopathogen Metarhizium anisopliae. Archives of Biochemistry and Biophysics 253, 221-232.

St Leger, R. J., CoOper, R. M. \& Charnley, A. K. (1987c). Distribution of chymoelastases and trypsin-like enzymes in five species of entomopathogenic deuteromycetes. Archives of Biochemistry and Biophysics 288, 123-131.

St Leger, R. J., Durrands, P. K., Charnley, A. K. \& Cooper, R. M $(1988 a)$. Role of extracellular chymoelastase in the virulence of Metarhizium anisopliae for Manduca sexta. Journal of Invertebrate Pathology 52, 285-293.

St Leger, R. J., Durrands, P. K., Cooper, R. M. \& Charnley, A. K. $(1988 b)$. Regulation of production of proteolytic enzymes by the entomopathogenic fungus Metarhizium anisopliae. Archives of Microbiology 150, 413-416.

St Leger, R. J., Butt, T. M., Staples, R. C. \& Roberts, D. W. $(1989 a)$. Synthesis of proteins including a cuticle-degrading protease during differentiation of the entomopathogenic fungus Metarhizium anisopliae. Experimental Mycology 13, 253-262.

St Leger, R. J., Butt, T., Goettel, M. S., StaPles, R. C. \& Roberts, D. W. $(1989 b)$. Production in vitro of appressoria by the entomopathogenic fungus Metarhizium anisopliae. Experimental Mycology 13, 274-288.

Sive, H. L. \& ST JoHN, T. (1988). A simple subtractive hybridization technique employing photoactivatable biotin and phenol extraction. Nucleic Acids Research 16, 10937.

Thompson, W. F., Everett, M., Dolans, N. O., Jorgensen, R. A. \& Palmer, J. D. (1983). Phytochrome control of RNA levels in developing peas and mung bean leaves. Planta 158, 487-500.

Williams, J. G., LloYd, M. M. \& DeRME, J. M. (1979). Characterization and transcription analysis of a cloned sequence derived from a major developmentally regulated mRNA of $D$. discoideum. Cell 17, 903-913.

Woloshuk, C. P. \& Kolattukudy, P. E. (1986). Mechanism by which contact with plant cuticle triggers cutinase gene expression in the spores of Fusarium solani f.sp. pisi. Proceedings of the National Academy of Sciences of the United States of America 83, 1704-1708. 